\title{
Enhancement of the After-Glow Properties of Photoluminescent Tile by Designing Frit Composition with Low-Temperature Melting
}

\author{
N.T. Selli And A. TunAli \\ Eczacibasi Building Product Co., VitrA Innovation Center, Bozuyuk/Bilecik, Turkey
}

\begin{abstract}
One of the persistent luminescence materials and providing emission in blue-green areas emission bands for typical phosphors $\left(\mathrm{SrAl}_{2} \mathrm{O}_{4}: \mathrm{Eu}^{2+}, \mathrm{CaAl}_{2} \mathrm{O}_{4}: \mathrm{Eu}^{2+}, \mathrm{MgAl}_{2} \mathrm{O}_{4}: \mathrm{Eu}^{2+}\right)$ are generally focused on recently. These systems are reliable, stable, not containing radiation and they have long term photoluminescence emission. These systems are mainly used in a wide range of products such as building, ceramics, line marks for highways, tolls, etc. In this study, $\mathrm{SrAl}_{2} \mathrm{O}_{4}: \mathrm{Eu}^{2+}$ phosphorescent pigment was used on wall tile surfaces. Due to the high firing temperature after-glow property of the pigment decreases. To increase afterglow property frit compositions with low temperature melting point were developed and depend on the composition, after-glow properties of the tiles were measured by photometer.
\end{abstract}

DOI: $10.12693 /$ APhysPolA.125.509

PACS: $78.55 . \mathrm{Hx}$

\section{Introduction}

Afterglow luminescence is cold light that needs to pump energy from some sources at certain temperature; in other words, the light intensity and delay time of afterglow is strongly dependent on temperature as well as the energy absorbed [1]. Photoluminescence is delayed luminescence that obtains energy from electromagnetic radiation, such as light $[2,3]$. Most afterglow phosphorescence behaviors are more or less related to temperature effect. Great attentions and significant interest of scientist, engineers and technologists are attracted for the use of afterglow phosphorescence in academic as well as practice in the past decade [4]. It is known that the persistent luminescence life time and intensities of phosphors can be enhanced by co-doping them with other rare earth ions. The phosphorescence from the aluminates is believed to be caused by the $4 f-5 d$ transition of $\mathrm{Eu}^{2+}$ ions in the crystal [5-8]. Frits are glass particles prepared by heating suitable batches to a high temperature in a gas or oil-fired furnace or in an electric melting unit. Batch constituents are chosen amongst the readily available inorganic raw materials [9].

In the present study, low melting transparent frit composition was synthesized and produced for glazed wall tile granule applications in order to achieve long lasting phosphorescence ability.

\section{Experimental procedure}

Since commercially available low melting transparent frits were found to be unsuitable for long afterglow ability, a new transparent frit composition (TG8) was synthesized and produced after 10 trials. Some of the studies are here discussed (Table I). In this table TG-3 is the base composition. Oxide ratio of secondary compositions was changed to observe best quality. Changes made were shown as underlined.

For frit preparation the weighed batch materials, after through mixing were melted in an alumina crucible
Compositions of the low temperature transparent frits (wt\%).

\begin{tabular}{c|c|c|c|c|c|c|c|c}
\hline \hline & $\mathrm{Na}_{2} \mathrm{O}$ & $\mathrm{K}_{2} \mathrm{O}$ & $\mathrm{CaO}$ & $\mathrm{MgO}$ & $\mathrm{BaO}$ & $\mathrm{Al}_{2} \mathrm{O}_{3}$ & $\mathrm{SiO}_{2}$ & $\mathrm{~B}_{2} \mathrm{O}_{3}$ \\
\hline TG-3 & 0.8 & 0.3 & 11.0 & 0.4 & 7.0 & 11.0 & 39.0 & 30.5 \\
TG-5 & $\underline{5.7}$ & $\underline{4.6}$ & $\underline{12.9}$ & - & - & 11.0 & $\underline{45.8}$ & $\underline{20.0}$ \\
TG-8 & 0.8 & 0.3 & 11.0 & 0.4 & 7.0 & $\underline{14.0}$ & 39.0 & $\underline{27.5}$ \\
TG-9 & 0.8 & 0.3 & $\underline{8.0}$ & 0.4 & 7.0 & 11.0 & $\underline{42}$ & 30.5
\end{tabular}

in an electric furnace at $1450^{\circ} \mathrm{C}$ for $1 \mathrm{~h}$. The melt was quenched by pouring into water to obtain a glassy frit. Frit particles were dried in an oven and dry-milled in an alumina ball mill to obtain granulated frit. The milled small frit granules were sieved in an automatic sieving machine. Ten percent of phosphorescent pigment was added to the granulated frit. Then, the phosphorescent pigment-added granule frit was applied onto glazed ceramic wall tiles for decoration purposes by screen printing. Industrial firing was conducted in a fast second-firing decoration furnace with a top temperature of $900{ }^{\circ} \mathrm{C}$ for a total firing cycle of $38 \mathrm{~min}$.

The sintering behaviour of frit was studied by a hot stage microscope (Misura 3.32 ODHT-HSM 1600/80) with a heating rate of $50^{\circ} \mathrm{C} / \mathrm{min}$ up to $400^{\circ} \mathrm{C}$ and $10^{\circ} \mathrm{C} / \mathrm{min}$ up to $1000^{\circ} \mathrm{C}$. Furthermore, the effect of frit composition on afterglow property is examined by using Photometer (LS-100, Konica, Minolta). After glow property was determined considering the glowness of the sample in darkness versus time.

\section{Results and discussion}

Figure 1 indicates sintering and shrinkage behaviour of synthesized frits and Table II shows their important temperatures obtained by hot stage microscope analyses. TG-3 frit contains high level of boric oxide and earth alkaline oxide and naturally all of its relevant values get lowest when compared to others. TG-3 melted totally due to its lowest fusion temperature and produced transparent smooth surface. That is why maximum level of 
afterglow ( $>250 \mathrm{mcd} / \mathrm{m}^{2}$ ) was observed after removing the light source (Fig. 2).

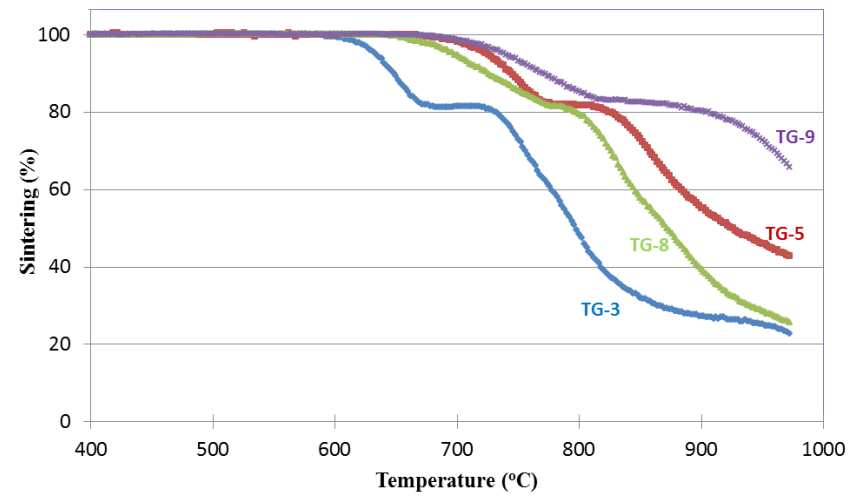

Fig. 1. Sintering behaviour of frit compositions obtained by hot stage microscope.

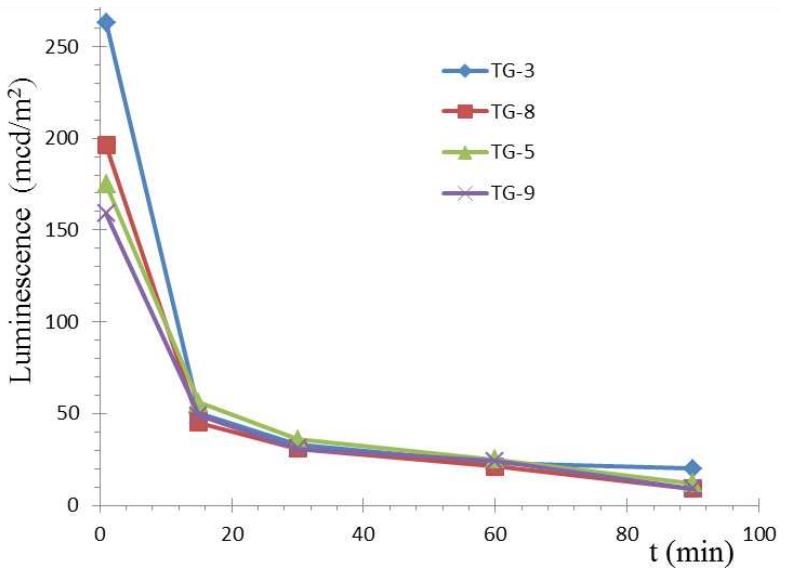

Fig. 2. Afterglow property of frit compositions.

TABLE II

The hot stage microscope analysis results of transparent frits shown in Fig. 1.

\begin{tabular}{c|c|c|c|c}
\hline \hline $\begin{array}{c}\text { Temperatures } \\
{\left[{ }^{\circ} \mathrm{C}\right]}\end{array}$ & TG-3 & TG-5 & TG-8 & TG-9 \\
\hline sintering & 634 & 726 & 698 & 740 \\
softening & 708 & 814 & 794 & 888 \\
sphere & 760 & 868 & 842 & - \\
half-sphere & 802 & 934 & 882 & 1018 \\
fusion & 828 & 998 & 912 & 1062
\end{tabular}

To obtain the desired decoration on wall tile, granules must not fully melt. Although TG-3 frit has low softening point and high afterglow, it could not give desired surface effect at this temperature.
Alkaline oxide ratio was increased in composition TG-5 to observe low-temperature frit. However, formation of cracks in the tile surface was observed in high amounts. It is known that increasing the amounts of alkaline compounds present in the glaze increases the coefficient of thermal expansion, and has a direct bearing upon crazing of the glaze [10]. Surface of the tile on which TG-9 frit was applied became rough at fired temperature. The best result was observed by TG- 8 in terms of afterglow property and tile surfaces.

When the afterglow property of glazes are compared, it is observed that frit composition affects the initial luminescence value. After a short time the effect of frit composition on luminescence disappears. After this time characteristic of phosphorescence pigment affects the luminescence value.

\section{Conclusions}

Low-temperature transparent frits were prepared and produced for ceramic wall tile. Results indicated that low temperature transparent frits can be used with phosphorescent pigment for second firing decoration purposes in order to increase afterglow property of wall tile surfaces. However, the effect of the composition of the frit is valid for a short period of time $(15 \mathrm{~min})$. After this time pigment characteristics are important on luminescence value.

\section{References}

[1] Y. Kamiyanagi, M. Kitaura, M. Kaneyoshi, J. Lumin. 122-123, 509 (2007).

[2] H.B. Yuan, J. Lumin. 4, 29 (2008).

[3] J. Guan, X. Cui, W. Zhung, C. Zhao, Y. Chang, J. Chin. Rare Earth Soc., 21 (2008).

[4] B.P. Chandra, R.N. Baghel, A.K. Luka, T.R. Sanodiya, R.K. Kuraria, S.R. Kuraria, J. Lumin. 129 , 760 (2009).

[5] S. Choi, N. Kim, Y. Yun, S.C. Choi, J. Ceram. Proc. Res. 7, 62 (2006).

[6] S. Kaya Yesilay, B. Karasu, G. Kaya, E. Karacaoglu, Adv. Sci. Technol. 62, 88 (2010).

[7] S. Kaya Yesilay, B. Karasu, E. Karacaoglu, in: The Proc. Book of the 15th Int. Metallurgy and Materials Congress, Istanbul, Eds.: C. Durucan, C.H. Gür, B. Özkal, H. Savaş, H.E. Ünalan, Türk Mühendis ve Mimar OdalarıBirliği, Metalurji Mühendisleri Odası, Ankara 2010, p. 2140.

[8] S. Kaya Yesilay, B. Karasu, Seramik Turkiye Magasine 1, 128 (2011).

[9] W. Jia, H. Yuan, L. Lu, H. Liu, M.W. Yen, J. Cryst. Growth 200, 179 (1999).

[10] J.W. Hinton, U.S. Patent No. 4,084,976, 18 April 1978. 